\title{
Dental Stem Cells Harvested from Third Molars Combined with Bioactive Glass Can Induce Signs of Bone Formation In Vitro
}

\author{
Gregorio Raspini', Jan Wolff², Mika Helminen ${ }^{3}$, Giovacchino Raspini ${ }^{4}$, Mario Raspini ${ }^{4}$, George K. \\ Sándor ${ }^{1,5}$ \\ ${ }^{1}$ Department of Oral and Maxillofacial Surgery, University of Oulu, Oulu, Finland. \\ ${ }^{2}$ Department of Oral and Maxillofacial Surgery/Pathology \& 3D Innovation Lab, VU University Medical Center, Amsterdam, \\ The Netherlands. \\ ${ }^{3}$ Faculty of Social Sciences, University of Tampere and Science Center, Pirkanmaa Hospital District, Tampere, Finland. \\ ${ }^{4}$ Private practice, Arezzo, Italy. \\ ${ }^{5}$ Tissue Engineering and Oral and Maxillofacial Surgery, Medical Research Center, University of Oulu and Oulu University \\ Hospital, Oulu, Finland.
}

\author{
Corresponding Author: \\ George K. Sándor \\ Department of Oral and Maxillofacial Surgery \\ University of Oulu \\ Aapistie 3A, FIN-90014 Oulu \\ Finland \\ E-mail: george.sandor@,oulu.fi
}

\begin{abstract}
Objectives: The aim of this study was to assess the interaction of a bioactive glass scaffold with cells derived from dental pulp, dental follicle and periodontal ligament.

Material and Methods: Impacted third molars were surgically removed from three young donors. Cells from the dental pulp, follicle and periodontal ligament tissues were isolated and expanded. Different cell populations were characterised using specific CD markers. Expanded pulp, follicle and periodontal cells were then seeded onto bioactive glass scaffolds and cultured in osteogenic medium or basic medium. Cell attachment, viability, proliferation and alkaline phosphatase activity were assessed.

Results: This study revealed good biocompatibility of the specific bioactive glass configuration tested and the osteogenic induction of cells derived from dental pulp, dental follicle and periodontal ligament. Osteogenic medium seemed to increase the differentiation pattern and dental pulp stem cells showed the most positive results compared to periodontal ligament and dental follicle stem cells.

Conclusions: Dental pulp stem cells combined with a bioactive glass scaffold and exposed to osteogenic medium in vitro represent a promising combination for future study of hard tissue regeneration in the cranio-maxillofacial skeleton.
\end{abstract}

Keywords: tissue engineering; third molar; stem cells; bone regeneration.

Accepted for publication: 20 February 2018

To cite this article:

Raspini G, Wolff J, Helminen M, Raspini G, Raspini M, Sándor GK.

Dental Stem Cells Harvested from Third Molars Combined with Bioactive Glass Can Induce Signs of Bone Formation In Vitro

J Oral Maxillofac Res 2018;9(1):e2

URL: http://www.ejomr.org/JOMR/archives/2018/1/e2/v9n1e2.pdf

doi: $10.5037 /$ jomr.2018.9102 


\section{INTRODUCTION}

Autogenous bone is still considered to be the gold standard for reconstructive surgery of the maxillofacial skeletal defects [1]. Harvesting bone, however, is accompanied by donor site morbidity and requires prolonged operative time [2]. The elimination of the autogenous bone graft donor site would be a major step forward in morbidity reduction. An alternative to treating bony defects is the tissue engineering approach.

Tissue engineering was first described by Langer and Vacanti [3] as an interdisciplinary field of research that applies both the principles of engineering and the processes and phenomena of the life sciences toward the development of biological substitutes that restore, maintain, or improve tissue function.

One possibility is to improve function using the reserve of stem cells within the body of an individual in order to regenerate missing or damaged structures. Stem cells have the unique ability to renew themselves through mitotic cell division and when it is needed, to differentiate into one or more types of specialized cells. Mesenchymal stem cells (MSCs) were first identified from bone marrow aspirates in rodents [4] and subsequently a similar clonogenic population was identified from human bone marrow [5]. Bone marrow stem cells (BMSCs) were transplanted with an osteoconductive scaffold into ectopic sites of immunocompromised mice in order to prove their ability to form bone $[6,7]$. Adipose derived stem cells (ASCs) have been used clinically in a case series to reconstruct major bony defects of the craniomaxillofacial skeleton [ $\underline{8}]$.

MSCs have been identified in different dental tissues such as dental pulp [9], periodontal ligament [10], dental follicle [11], the pulp of deciduous exfoliated teeth [12], and dental apical papilla $[\underline{13}, \underline{14}]$. Dental stem cells (DSCs) have been differentiated into different mesenchymal cell lineages such as adipocytes, chondroblasts and osteoblasts under defined inductive conditions in vitro [15-18].

DSCs have been harvested from the various tissues of extracted third molars, which until now, have been discarded after surgery [18]. This source of adult stem cells has the advantage of being autologous, without the ethical or immunologic issues related to embryonic stem cells. DSCs harvesting during otherwise necessary third molar extraction does not result in any additional morbidity to the patient compared to harvesting BMSCs or ASCs which require an additional surgical site.

However, while stem cells are one key factor they are not the only players in the tissue engineering paradigm. Resorbable scaffolds and bioactive molecules can also interact with each other as well as with stem cells [19].

A wide range of biomaterials have been used in the past as scaffolds in bone tissue engineering [20] including bioactive glasses [21]. These synthetic, silica based group of bone substitute materials have been proven to be bioactive and to bond directly to bone at its surface [22]. The release of soluble ions resulting from the dissolution of bioactive glasses can increase osteoblast proliferation and therefore enhance bone formation [23]. The ability of bioactive glass scaffold to promote bone bonding and bone formation through both surface-mediated and solution-mediated mechanisms have made it a promising bone tissue engineering scaffold that supports both proliferation and osteogenic differentiation of adipose derived stem cells $[\underline{24}, \underline{25}]$.

Cytokines and growth factors such as bone morphogenetic proteins (BMPs) have been used as osteoinductive molecules to promote osteogenic differentiation and have shown promising results in vivo [26]. The high costs of growth factors and concerns with their use in supra-physiologic doses have encouraged the development of osteogenic medium $(\mathrm{OM})$ as an alternative for MSCs differentiation in bone engineering [27].

The combination of DSCs with bioactive glass has not been studied together and is an important step in understanding the biocompatibility of this biomaterial with DSCs. This study aimed to assess the combination of a bioactive glass scaffold with stem cells harvested from dental pulp, dental follicle and periodontal ligament stem cells.

\section{MATERIAL AND METHODS \\ Tooth extraction, cells isolation and culture}

Impacted third molars were extracted at the Finnish Student Health Service of Tampere University from three healthy volunteer donors aged from 19,21 and 25 years. The collection of stem cells from tooth samples and their ex vivo treatment was approved by the Ethics Committee of the Pirkanmaa Hospital District, Tampere, Finland (R06009).

One or more teeth were surgically removed from each of the three patients and placed into separate $15 \mathrm{ml}$ Falcon tubes for immediate transport from the operating room to the cell culturing laboratory where the individual tissues were harvested under laminar flow hoods. Follicular tissue was harvested first by removing the sac-like follicle to the cemento- 
enamel junction (CEJ). Periodontal ligament tissue was harvested with a scalpel by scraping the tooth roots apical to the CEJ, but coronal to any apical papilla tissue. Dental pulp tissue was collected after sectioning the crown of the freshly extracted molar away from its roots using a drill with sterile irrigation. The pulp tissue was harvested from the opened pulp chamber using a scalpel and a curette. The collected tissue was cut into small pieces using a sterile number 15 scalpel and put into a Falcon tube each labelled by patient and the specific tissue of origin being follicle, pulp, or periodontal ligament. Each of the three tissues were cultured separately.

The following procedures reported by Lindroos et al. [15] were used to isolate the dental stem cells. Dental pulp, follicle and periodontal ligament tissues were transferred in separate $15 \mathrm{ml}$ Falcon tubes with a solution consisting of Dolbecco's phosphate-buffered saline (DPBS) (Lonza, BioWhittaker, Walkersville, $\mathrm{MD}$, USA) and $1 \%$ Antibiotic-Antimycotic (a/a; $100 \mathrm{U} / \mathrm{ml}$ penicillin, $0.1 \mathrm{mg} / \mathrm{ml}$ streptomycin, and $0.25 \mathrm{mg} / \mathrm{ml}$ amphotericin B; Invitrogen Gibco/Life Technologies, Carlsbad, CA, USA).

Briefly, the pieces of dental tissues were digested with $2 \mathrm{ml}$ of Dispase $4 \mathrm{mg} / \mathrm{ml}$ and Collagenase type I $3 \mathrm{mg} /$ $\mathrm{ml}$ (Gibco/Life Technologies) solution in a water bath at $37^{\circ} \mathrm{C}$ for one hour. After centrifugation and removal of the supernatant the resultant pellet was suspended in $3 \mathrm{ml}$ of growth medium and then the cells plated in a 6 well plate with a $100 \mathrm{~mm}$ cell strainer.

The different populations of human dental stem cells (hDSCs) from each donor's sample consisted of separately cultured periodontal ligament stem cells (hPDLSCs ), dental pulp (hDPSCs ) and dental follicle (hDFSCs). These cells were expanded in separate $\mathrm{T} 75 \mathrm{~cm}^{2}$ polystyrene flasks (Nunc, Roskilde, Denmark) in maintenance medium.

The control or Basic Medium (BM) consisted of DMEM/F12 (Gibco), 10\% Foetal Bovine Serum (FBS) (Gibco), 1\% L-glutamine (GlutaMAX 100X-Gibco), 1\% Antibiotic-Antimycotic (a/a; $100 \mathrm{U} /$ $\mathrm{ml}$ penicillin, $0.1 \mathrm{mg} / \mathrm{ml}$ streptomycin, and $0.25 \mathrm{mg} /$ $\mathrm{ml}$ amphotericin B; Invitrogen Gibco).

The attachment of hDSCs were evaluated microscopically (Nikon eclipse TS100) beginning one day following isolation. When confluency was reached the cells were detached and divided into T75 $\mathrm{cm}^{2}$ flasks. Medium change occurred every two or three days and the cell passages between 2 and 5 were used in these experiments. After expansion, hDSCs were cryo-preserved in gas phase nitrogen freezing solution consisting of $10 \%$ dimethyl sulphoxide (Hybri-Max; Sigma-Aldrich, St. Louis, MO, USA) in foetal bovine serum.

\section{Cell characterization}

The expression of surface markers of hDSCs were characterised using a flow cytometry (FACSAria; BD Biosciences, Erembodegem, Belgium). The following monoclonal antibodies were used: CD19-phycoerythrin-Cyanine (PECy7), CD45ROallophycocyanin (APC), CD54-fluorescein isothiocyanate (FITC), CD73-phycoerythrin (PE), CD 90-APC, (BD Biosciences), FGFR-2-APC, FGFR3PE, ALP-APC, BMPR-IA-fluorescein isothiocyanate (FITC), TGF- $\beta 1$ (LAP)-PE, VEGF R1-PE, VEGF R2-Peridinin-chlorophyll (PerCP), VEGF R3-APC, CD11a-APC, CD54-FITC, CD80-PE, CD86-PE, CD 105-PE (R\&D Systems, Minneapolis, MN, USA), and CD34-APC, HLADR-PE (Immunotools $\mathrm{GmbH}$, Friesoythe, Germany). Three intracellular markers were also characterised from the same cells: VEGFPE, Latent TGF- $\beta$-PE, Twist-1-FITC (R\&D Systems, Minneapolis, MN, USA) Analysis was performed on 100,000 cells per sample and the positive expression was defined as the level of fluorescence greater than $99 \%$ of the corresponding unstained cell sample.

\section{Biomaterial preparation}

BioRestore $^{\mathrm{TM}}$ (Inion, Tampere, Finland) is a commercially available biomaterial, already in use as a bioactive glass scaffold for bone grafts in clinical dentistry. BioRestore has a nominal composition of $11.1-12 \mathrm{wt} \% \mathrm{Na}_{2} \mathrm{O}, 15-17.1 \mathrm{wt} \% \mathrm{~K}_{2} \mathrm{O}, 2.8-$ $3.3 \mathrm{wt} \% \mathrm{MgO}, 12.7-15.2 \mathrm{wt} \% \mathrm{CaO}, 2.7-3.8 \mathrm{wt} \%$ $\mathrm{P}_{2} \mathrm{O}_{5}, 1-1.4 \mathrm{wt} \% \mathrm{~B}_{2} \mathrm{O}_{3}, 0-0.6 \mathrm{wt} \% \mathrm{TiO}_{2}$ and 48.5 - $52 \mathrm{wt} \% \mathrm{SiO}_{2}$. The scaffold porosity was $70 \%$ and scaffold proportions of $7 \times 7 \times 3 \mathrm{~mm}$ were used as three-dimensional carriers of osteoinductive material for the seeding of hDSCs in this study. The scaffolds were first sterilised with $70 \%$ ethanol for one hour and washed with DPBS (Lonza, Valais, Switzerland) several times to avoid any ethanol entrapment inside the scaffold and to remove fibres detached from the scaffolds. The scaffolds were plated in a 24 well plates with $1 \mathrm{ml}$ of $\mathrm{BM}$ which was enough to cover the scaffold, and incubated for 48 hours at $37^{\circ} \mathrm{C}$ in $5 \% \mathrm{CO}_{2}$.

\section{Cell seeding}

Cells were seeded onto scaffolds at a density of 9.7 x $10^{4}$ cells per scaffold with $50 \mu 1$ of maintenance medium. The cells were allowed to attach for 3 hours at $37{ }^{\circ} \mathrm{C}$ and $5 \% \mathrm{CO}_{2}$. After 3 hours 1 $\mathrm{ml}$ of $\mathrm{BM}$ was added to half of the scaffolds and $1 \mathrm{ml}$ of osteogenic medium (OM) was added to 
the remaining scaffolds for differentiation study. In addition to the constituents of $\mathrm{BM}$, the $\mathrm{OM}$ contained $\beta$-glycerophoshate, dexamethasone and L-ascorbic acid. The OM specifically consisted of: DMEM/F12, 10\% Foetal Bovine Serum (FBS-Gibco), 1\% L-glutamine (GlutaMAX 100X-Gibco), 1\% Antibiotic-Antimycotic (Gibco/Life Technologies, Carlsbad, CA, USA), $100 \mathrm{nM}$ dexamethasone (Sigma-Aldrich, St. Louis, MO, USA), $50 \mu \mathrm{M}$ L-ascorbic acid 2-phosphate (Sigma-Aldrich, MO, USA), $10 \mathrm{mM} \beta$-glycerophoshate (Sigma-Aldrich, MO, USA). The medium was changed three times a week.

\section{Cell attachment and viability}

The evaluation of $\mathrm{hDSCs}$ attachment and viability on the bioactive glass scaffolds was performed qualitatively using Live/dead-staining probes (Molecular Probes/Invitrogen, Eugene, OR, USA) at day 7 and 14 .

A mixture of $0.5 \mu \mathrm{M}$ calcein acetoxymethyl ester (Molecular Probes) and $0.25 \mu \mathrm{M}$ ethidium homodimer-1 (Molecular Probes) were used to stain viable and necrotic cells. The combination of hDSCs and bioactive glass scaffolds were covered and incubated with the above mentioned solution for 45 minutes in a dark room. The viable cells with green fluorescence and the dead cells with red fluorescence could be visualized using an Olympus IX51 phase contrast microscope with fluorescence optics (Olympus, Tokyo, Japan). Multiple images were captured with an Olympus DP30BW camera (Olympus, Tokyo, Japan).

\section{Cell proliferation}

Cell proliferation was evaluated with a Cy QUANT Cell Proliferation Assay Kit (CyQUANT; Molecular Probes) at the 7,14 and 21 day time points.

This method evaluated DNA amount measuring the fluorescence which CyQuant GR dye expressed when bound to cellular nucleic acids. The cells were first lysated using $0.1 \%$ Triton-X 100 (Sigma-Aldrich, St. Louis, MO, USA) and then frozen immediately at $-81{ }^{\circ} \mathrm{C}$ to facilitate cell membrane breakage. After one night incubation at $-81{ }^{\circ} \mathrm{C}$ the cells were thawed and then each sample was collected in $1 \mathrm{ml}$ eppendorf tubes. The tubes were spun to allow possible biomaterial residuals to precipitate before three parallel samples of $20 \mathrm{ml}$ from each tube were added to a new 96-well plate (Nunc, Roskilde, Denmark). A solution with CyQuant GR dye, Cell-lysis buffer and deionized $\mathrm{H}_{2} \mathrm{O}$ was prepared according to the manufacturer's instructions and added to the 96well plate samples. The plate was covered from light before measuring the fluorescence at 480/520 nm with a microplate reader (Victor 1420 Multilabel Counter; Wallac, Turku, Finland).

\section{Alkaline phosphatase activity}

Alkaline phosphatase (ALP) activity was evaluated quantitatively at 7,14 and 21 days. The cell-seeded scaffolds were freeze-thawed twice before the ALP activity was evaluated. From each sample of $500 \mathrm{ul}$ cell lysate three parallel samples of 20 ul were used for this test.

The working solution consisted of Stock substrate solution (P-nitrophenol phosphate-Sigma-Aldrich) and alkaline buffer solution (2-amino-2-methyl-1propanol-Sigma-Aldrich) and $90 \mathrm{ul}$ of this solution was added to each parallel sample and then incubated at $37{ }^{\circ} \mathrm{C}$ for $15 \mathrm{~min}$. A total of $50 \mu \mathrm{L}$ of $\mathrm{NaOH}$ (1 M, Sigma-Aldrich) were added immediately after incubation to stop the reaction.

The yellow coloured P-nitrophenol amount, which was the result of ALP cleavage of phosphate groups from P-nitrophenol-phosphate, was measured at 405 $\mathrm{nm}$ using a Victor 1420 microplate reader (Victor Scientific, Ambala, India).

\section{Statistical analysis}

Statistical analyses were performed using linear mixed-effect models using proliferation (fluorescein) and ALP activity (absorbance) data, and also separately for ALP activity normalized to DNA amount. Models were constructed using the function "Imer" in the R Software Environment for Statistical Computing and Graphics, version 2.13.0 (The R Foundation for Statistical Computing, Vienna, Austria). The logarithmic absorbance variable was used in absorbance models due to an otherwise skewed distribution. Separate models were estimated for BM and OM, separately for 7, 14 and 21 days, when the cell types (hPDLSCs, hPSCs, hDFSCs) were compared. Likewise separate models for the different cell types and different time points were estimated when BM and OM were compared. Finally models including medium, cell types, linear time ( 7 , 14 and 21 days) and also squared time-variable- were estimated for examining overall changes between time points. The cell type hPSCs or BM was used as a reference group. Random intercept for three repeated measurements of each sample were used together with independent random errors in all models. 


\section{RESULTS}

\section{Characterization of hDSCs}

Cell surface and intracellular marker expression of hDSCs was analysed by flow cytometry to compare the expression profile of cells extracted from different compartments including dental pulp, follicle and PDL (Figure 1). In general, the different hDSCs showed similar marker expression characteristics with some minor differences observed between hDSC types. The hDSCs showed strong expression $(>90 \%)$ for the markers CD73 (Ecto 5' nucleotidase), CD90 (Thy-1) and CD105 (Endoglin). In contrast, hDSCs lacked (< $2 \%$ ) or had low expression $(\leq 10 \%)$ of CD11a (Integrin alpha-L), CD19 (B4), CD34 (the hematopoietic progenitor and endothelial cell marker), CD45 (leukocyte common antigen), CD80 (B7-1), CD86 (B7-2) and HLA-DR (Major histocompatibility class II receptor). The largest variation between different hDSCs was seen in the expression of CD54, which showed lower expression in hDFSCs and hDPSCs. Twist-1 was strongly expressed in hDSCs (77 99\%). The expression of ALP varied between donors and hDSCs type, being strongest in hDFSCs. The expression of growth factor receptors FGFR2 and -3 , BMPR-1A and VEGFR1, -2 and -3 was generally low with few exceptions. The expression of VEFGR1 was above $20 \%$ in hPDLSCs. The expression of growth factor TGF- $\beta 1$ was low to moderate, varying from 1 to $17 \%$ of the cells. In contrast, the expression of VEGF was strong in hDSCs. Its expression, however, varied dramatically between hDPSC donors (15 - 93\%).

\section{Cell attachment and viability}

Live-dead staining images of the bioglass scaffolds seeded with hDSCs revealed good biocompatibility, allowing attachment and survival of all of the types of dental stem cells tested. The cells spread on the biomaterial's fibres and changed their morphology to a more flattened shape compared to spindle shape in the plastic-cell culture wells. Furthermore hDSCs viability was also high and the number of red spots which represented dead cells was low or even absent at all of the time points (Figure 2).

\section{Cell attachment and survival}

The cells seeded onto one side of the bioactive glass scaffolds seemed to proliferate both inside and at the edges of the scaffold, completely reaching every part of the squared scaffolds. At 14 days some cell aggregates were clearly visible with a thin cell layer evident on the same side where the cells had been seeded. At 21 days this cell layer seemed to propagate to the lateral sides of the scaffold and eventually onto the opposite side. While cells were scattered throughout the scaffold the largest cell sheets were visible on the scaffold surfaces.

Linear mixed-effect analysis demonstrated a quadratic effect with time in proliferation rate. hDPSCs with BM showed a steady increase in cell numbers. hDPSCs with OM as well as hPDLSCs and hDFSCs with $\mathrm{BM}$ and $\mathrm{OM}$ all show an increase in cell numbers from day 7 to day 14 and a decrease from day 14 to day 21 (Figure 3A). There were sporadic bursts in proliferation at 21 days, depending on the cell donor. $\mathrm{OM}$ had a strong effect on proliferation only for hDPSCs, where OM showed lower values compared to BM. Dental follicle cells revealed the highest values of fluorescein independent of the medium used compared to the other cell types.
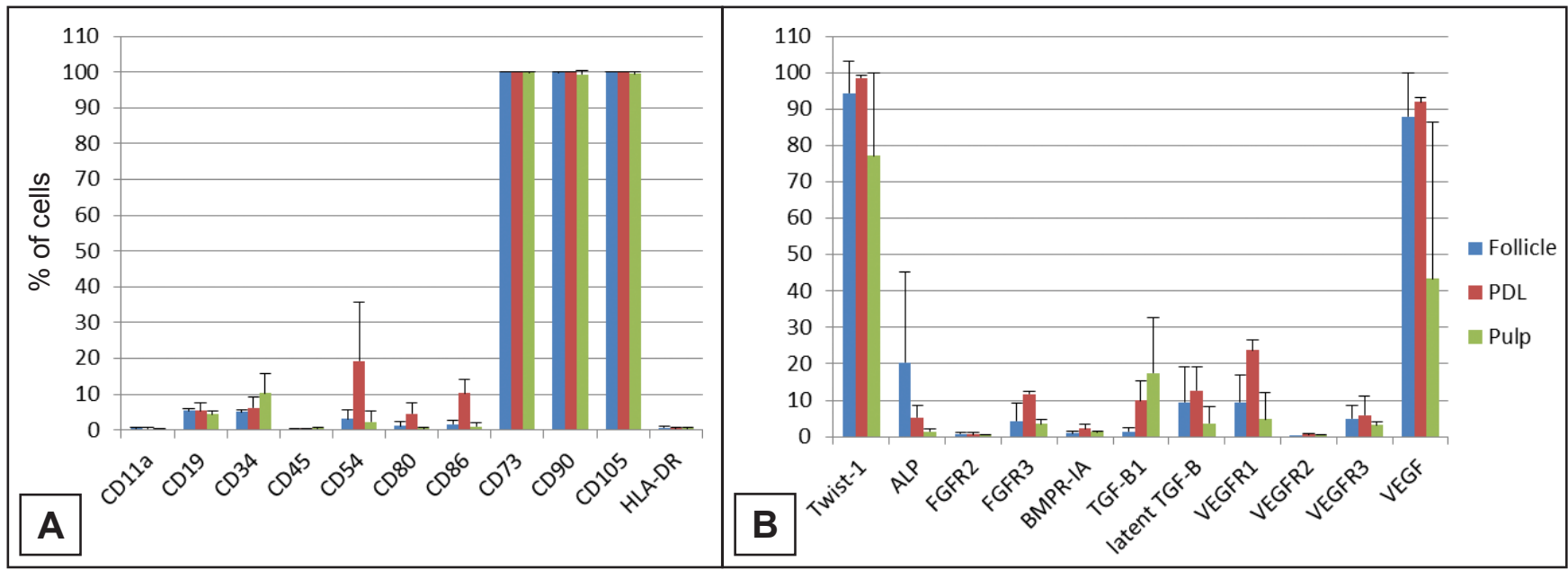

Figure 1. Characterization data of hDSCs by flow cytometry (hPDLSCs (PDL), hDPSCs (Pulp), hDFSCs (Follicle) where A and B list the $\mathrm{CD}$ markers and receptors tested. 


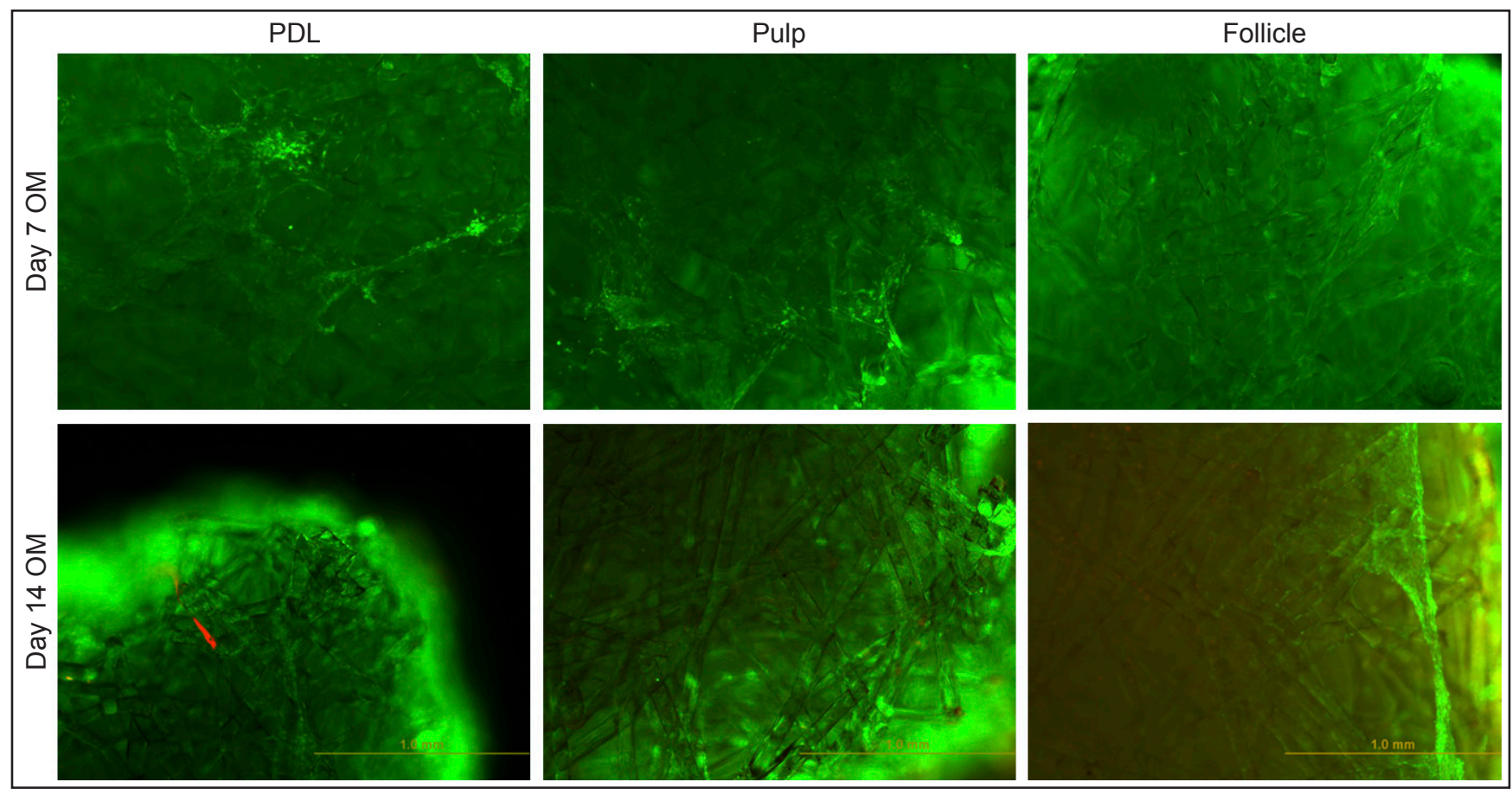

Figure 2. Attachment and viability of hPDLSCs (PDL), hDPSCs (pulp) and hDFSCs (Follicle) when cultured on bioactive glass scaffolds for 7 and 14 days. The live/dead-staining stains viable cells green and dead cells as red.

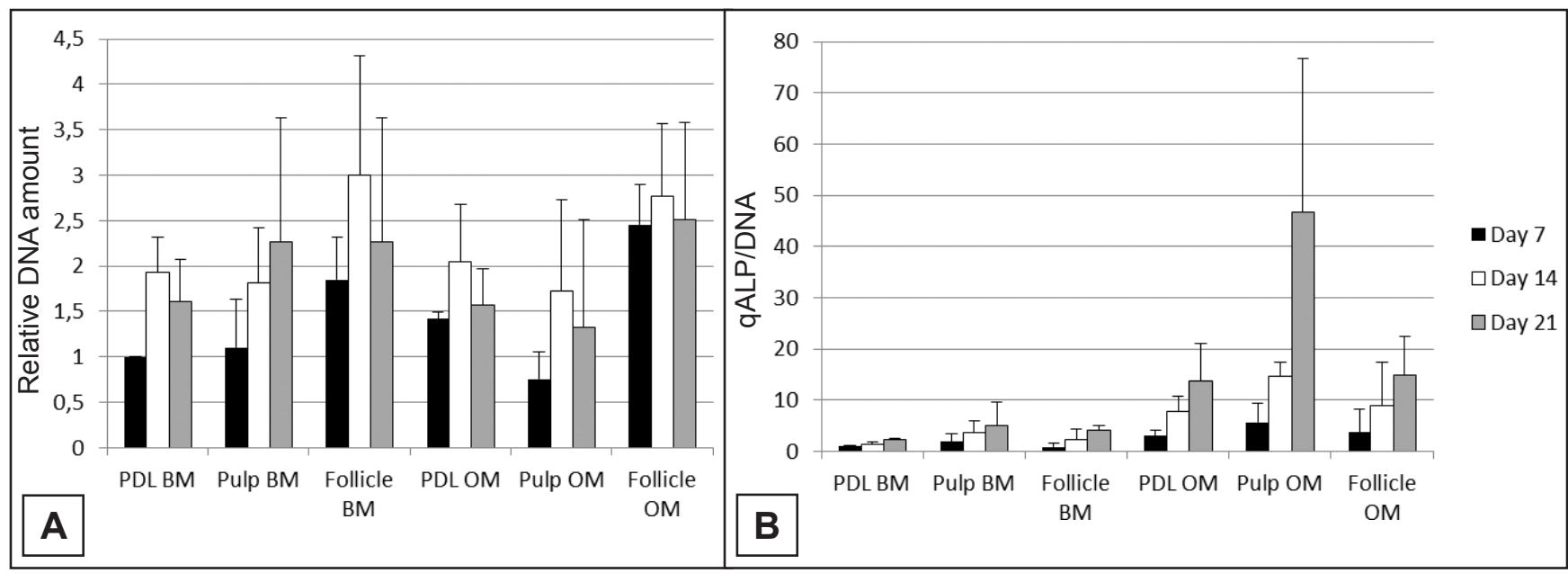

Figure 3. Relative DNA amount (A) and quantitative ALP activity normalized to DNA amount (B) of hPDLSCs (PDL), hDPSCs (Pulp) and hDFSCs (Follicle) when cultured on bioactive glass scaffolds in basic (BM) or osteogenic (OM) medium for 7, 14 and 21 days.

\section{Osteogenic differentiation and ALP activity}

ALP activity was evaluated quantitatively (Figure 3B). The results showed the superiority of OM in inducing osteogenic differentiation of the dental stem cells independently of the stem cell population used. The ALP activity increased from day 7 to day 21 for each cell type and medium used.

When tested with BM the hDPSCs showed highest normalized ALP values at all three time points. The ALP values with OM show a difference with hDPSCs compared to hPDLSCs and hDFSCs at 21 days. At day 7 and day 14 the DPSCs showed higher ALP values.

\section{DISCUSSION}

This study attempted to profile the expression of surface markers of three different populations of DSCs. One interesting finding was the notably high expression of Twist-1 and VEGF by all three types of DSCs.

This in vitro study followed an approach similar to that described by Tirkkonen et al. [27] with adipose derived stem cells. The current study, however, used a variety of human DSCs and tested them with a commercially available bioactive glass scaffold. The advantages of this approach included the existence of 
an already optimized in vitro protocol for isolating and expanding cells as well as culturing on the bioactive glass biomaterial using a similar protocol which had already been tested in vivo [27].

One major limitation of the study is related to the very limited number of participants, specifically three individuals. While this is a small number to draw conclusions from, still it is a beginning. The use of the term "biocompatibility" deserves discussion. With the complexity of immune responses and repair functions in the body, it may not be adequate to describe the biocompatibility of a biomaterial in relation to a single cell types, as a battery of in vitro tests do not determine the biocompatibility of a material, rather they just constitute an important step towards the casdcade of in vivo animal testing and future clinical trials.

Another disadvantage in the current study was the use of foetal bovine serum (FBS) instead of human serum as this could pose difficulty in translating these results to future applications. However, the source of serum does not seem to be so important as the results showed that hDSCs had comparable proliferation and differentiation values whether cultured in $20 \%$ Human serum or $10 \%$ FBS [17]. This justifies the opportunity to use this much less expensive medium in this preliminary in vitro step [17]. The results of this study show the potential role that the osteogenic medium may play in the differentiation of different populations of stem cells in vitro. This underscores the need to search for ideal combinations of bioactive molecules [16-18] and scaffolds [25,27] that facilitate the differentiation of stem cells and that could eventually be used safely in a future clinical environment.

This study showed that the OM was able to induce more profound differentiation than the BM. Nonetheless, the current results were obtained in vitro and may not be representative of the in vivo setting.

In a previous in vitro study Tirkkonen et al. [2]] showed the superiority of the OM compared to other growth factors such as VEGF, BMP7 and BMP2 in the differentiation of adipose derived stem cells. The differentiation process follows a very complex and still unknown mechanism where cell behaviour, biomaterial properties and osteoinductive molecules play an interconnected role.

The current results confirm the biocompatability of a bioactive glass scaffold, Biorestore ${ }^{\mathrm{TM}}$, allowing the proliferation of the cells seeded onto its surface. While this bioactive glass configuration supported osteogenic differentiation of the different dental stem cells seeded on to it, Tirkkonnen et al. [27] have already shown with ASCs that the use of the OM greatly improves this capacity.
These results are also in agreement with the observation that bioactive glass scaffolds increase osteogenic differentiation through both the release of soluble factors and by surface-contact mechanism. The structure of this scaffold allowed the proliferating cells to be mostly spreading on the top and at the edge of the squared block and this fact could be one of the reasons why the differentiation was also more evident in these areas. The explanation of this phenomenon could be also the fact that the nutrients and molecules contained in the medium could reach the external areas better than the middle and inner areas of this scaffold which are in a more static and isolated environment. A recent study showed that a dynamic environment could be advantageous for the differentiation of a threedimensional scaffold that exceeds $1 \mathrm{~mm}$ in vitro [28], but the same phenomena could be present in vivo.

The analysis of the difference between the three different populations of dental stem cells tested in this study showed that when supported with BM the dental pulp stem cells reach higher ALP values at 7, 14 and also 21 days compared to periodontal ligament stem cells and follicle stem cells. When samples were treated with osteogenic medium the dental pulp stem cells once again showed the highest ALP values at 21 days and they were consistently higher than with maintenance medium. The similarities in between bone and dentin is one possible reason that explains the higher ALP values of dental pulp stem cells compared to the other cell lines.

Recent studies have reported regeneration of human bone in vivo using dental pulp stem cells combined with collagen biocomplexes supporting the concept that hDSCs could be used as a potential source of cells for bone regeneration or to test future hard tissue regeneration biomaterials [29]. The current in vitro study also supports this concept [30].

In vivo animal studies confirm that stem cells combined with an osteoconductive biomaterial are committed to regenerate the same tissue from where they have been harvested $[\underline{30}, \underline{31}]$. Human studies show that a multi-potent population of dental pulp stem cells is able to form bone in vivo if implanted in a bone defect without any other osteoinductive biomaterial except for a collagen sponge $[29,32]$. It could be deduced from these observations that if in vitro the induction is fundamental, then the in vivo environment into which the cells are implanted will also be a factor, together with the biomaterial used. Probably the induction is an aspect coordinated by 
the host environment. There is growing evidence that dental pulp stem cells in the paradigm of bone tissue engineering may be a successful approach and that DSCs may be advantageous over BMSCs.

The growth potential shown by DPSCs, and the fact that DSCs are neural crest derived, as is craniofacial bone, supports the possibility that biologically DPSCs could be used to regenerate bone or other calcified tissues in the cranio-maxillofacial area. [3335]. Moreover the low morbidity of the otherwise necessary extraction of a tooth compared to the harvesting of bone marrow or adipose tissue aspirates supports the evaluation the role of $\mathrm{hDSCs}$ in bone regeneration.

Despite the fact that only three patients were enrolled in this study, their cells were continuously kept separated and not pooled together with the different patients. This strengthens the case for harvesting dental pulp and other dental stem cells from a single patient to study bone regeneration.

\section{CONCLUSIONS}

The use of dental stem cells for bone regeneration could be one future approach to treat bone defects of the cranio-maxillofacial skeleton. In vitro tests are fundamental first steps before translating this technology from the laboratory to clinical application.

\section{ACKNOWLEDGMENTS AND DISCLOSURE STATEMENTS}

The authors wish to thank Professor Susanna Miettinen and the staff of BioMediTech, Institute of Biosciences and Medical Technology, University of Tampere, Tampere, Finland for their help in this project.

This research did not receive any specific grant from funding agencies in the public, commercial, or notfor-profit sectors.

The authors have no conflicts to disclose.

\section{REFERENCES}

1. Jan A, Sándor GK, Brkovic BB, Peel S, Kim YD, Xiao WZ, Evans AW, Clokie CM. Effect of hyperbaric oxygen on demineralized bone matrix and biphasic calcium phosphate bone substitutes. Oral Surg Oral Med Oral Pathol Oral Radiol Endod. 2010 Jan;109(1):59-66. [Medline: 19846327] [doi: 10.1016/j.tripleo.2009.07.036]

2. Sàndor GK, Rittenberg BN, Clokie CM, Caminiti MF. Clinical success in harvesting autogenous bone using a minimally invasive trephine. J Oral Maxillofac Surg. 2003 Feb;61(2):164-8. [Medline: 12618991] [doi: 10.1053/joms.2003.50042]

3. Langer R, Vacanti JP. Tissue engineering. Science. 1993 May 14;260(5110):920-6. [Medline: 8493529] [doi: $10.1126 /$ science.8493529]

4. Friedenstein AJ, Gorskaja JF, Kulagina NN. Fibroblast precursors in normal and irradiated mouse hematopoietic organs. Exp Hematol. 1976 Sep;4(5):267-74. [Medline: 976387]

5. Castro-Malaspina H, Gay RE, Resnick G, Kapoor N, Meyers P, Chiarieri D, McKenzie S, Broxmeyer HE, Moore MA. Characterization of human bone marrow fibroblast colony-forming cells (CFU-F) and their progeny. Blood. 1980 Aug;56(2):289-301. [Medline: 6994839]

6. Haynesworth SE, Goshima J, Goldberg VM, Caplan AI. Characterization of cells with osteogenic potential from human marrow. Bone. 1992;13(1):81-8. [Medline: 1581112] [doi: 10.1016/8756-3282(92)90364-3]

7. Kuznetsov SA, Friedenstein AJ, Robey PG. Factors required for bone marrow stromal fibroblast colony formation in vitro. Br J Haematol. 1997 Jun;97(3):561-70. [Medline: 9207401] [doi: 10.1046/j.1365-2141.1997.902904.x]

8. Sándor GK, Numminen J, Wolff J, Thesleff T, Miettinen A, Tuovinen VJ, Mannerström B, Patrikoski M, Seppänen R, Miettinen S, Rautiainen M, Öhman J. Adipose stem cells used to reconstruct 13 cases with cranio-maxillofacial hard-tissue defects. Stem Cells Transl Med. 2014 Apr;3(4):530-40. [Medline: 24558162] [PMC free article: 3973720] [doi: $10.5966 /$ sctm.2013-0173]

9. Gronthos S, Mankani M, Brahim J, Robey PG, Shi S. Postnatal human dental pulp stem cells (DPSCs) in vitro and in vivo. Proc Natl Acad Sci U S A. 2000 Dec 5;97(25):13625-30. [Medline: 11087820] [PMC free article: 17626] [doi: 10.1073/pnas.240309797]

10. Seo BM, Miura M, Gronthos S, Bartold PM, Batouli S, Brahim J, Young M, Robey PG, Wang CY, Shi S. Investigation of multipotent postnatal stem cells from human periodontal ligament. Lancet. 2004 Jul 10-16;364(9429):149-55. [Medline: 15246727] [doi: 10.1016/S0140-6736(04)16627-0]

11. Handa K, Saito M, Tsunoda A, Yamauchi M, Hattori S, Sato S, Toyoda M, Teranaka T, Narayanan AS. Progenitor cells from dental follicle are able to form cementum matrix in vivo. Connect Tissue Res. 2002;43(2-3):406-8. [Medline: 12489190] [doi: 10.1080/03008200290001023]

12. Miura M, Gronthos S, Zhao M, Lu B, Fisher LW, Robey PG, Shi S. SHED: stem cells from human exfoliated deciduous teeth. Proc Natl Acad Sci U S A. 2003 May 13;100(10):5807-12. [Medline: 12716973] [doi: 10.1073/pnas.0937635100] 
13. Sonoyama W, Liu Y, Fang D, Yamaza T, Seo BM, Zhang C, Liu H, Gronthos S, Wang CY, Wang S, Shi S. Mesenchymal stem cell-mediated functional tooth regeneration in swine. PLoS One. 2006 Dec 20;1:e79. [Medline: 17183711] [PMC free article: 1762318] [doi: 10.1371/journal.pone.0000079]

14. Sonoyama W, Liu Y, Yamaza T, Tuan RS, Wang S, Shi S, Huang GT. Characterization of the apical papilla and its residing stem cells from human immature permanent teeth: a pilot study. J Endod. 2008 Feb;34(2):166-71. [Medline: 18215674] [PMC free article: 2714367] [doi: 10.1016/j.joen.2007.11.021]

15. Lindroos B, Mäenpää K, Ylikomi T, Oja H, Suuronen R, Miettinen S. Characterisation of human dental stem cells and buccal mucosa fibroblasts. Biochem Biophys Res Commun. 2008 Apr 4;368(2):329-35. [Medline: 18230338] [doi: 10.1016/j.bbrc.2008.01.081]

16. Khanna-Jain R, Mannerström B, Vuorinen A, Sándor GK, Suuronen R, Miettinen S. Osteogenic differentiation of human dental pulp stem cells on $\beta$-tricalcium phosphate/poly (l-lactic acid/caprolactone) three-dimensional scaffolds. J Tissue Eng. 2012;3(1):2041731412467998. [Medline: 23316276] [PMC free article: 3540691] [doi: 10.1177/2041731412467998]

17. Khanna-Jain R, Vuorinen A, Sándor GK, Suuronen R, Miettinen S. Vitamin D(3) metabolites induce osteogenic differentiation in human dental pulp and human dental follicle cells. J Steroid Biochem Mol Biol. 2010 Oct;122(4): 133-41. [Medline: 20723601] [doi: 10.1016/i.jsbmb.2010.08.001]

18. Khanna-Jain R, Agata H, Vuorinen A, Sándor GK, Suuronen R, Miettinen S. Addition of BMP-2 or BMP-6 to dexamethasone, ascorbic acid, and $\beta$-glycerophosphate may not enhance osteogenic differentiation of human periodontal ligament cells. Growth Factors. 2010 Dec;28(6):437-46. [Medline: 20569096] [doi: 10.3109/08977194.2010.495719]

19. Sándor GK. Tissue engineering: Propagating the wave of change. Ann Maxillofac Surg. 2013 Jan;3(1):1-2. [Medline: 23662250] [PMC free article: 3645600] [doi: 10.4103/2231-0746.110058]

20. Wolff J, Sándor GK, Miettinen A, Tuovinen VJ, Mannerström B, Patrikoski M, Miettinen S. GMP-level adipose stem cells combined with computer-aided manufacturing to reconstruct mandibular ameloblastoma resection defects: Experience with three cases. Ann Maxillofac Surg. 2013 Jul;3(2):114-25. [Medline: 3814659] [PMC free article: 3814659] [doi: $10.4103 / 2231-0746.119216]$

21. Saravanapavan P, Jones JR, Verrier S, Beilby R, Shirtliff VJ, Hench LL, Polak JM. Binary CaO-SiO(2) gel-glasses for biomedical applications. Biomed Mater Eng. 2004;14(4):467-86. [Medline: 15472395]

22. Hench LL, Xynos ID, Polak JM. Bioactive glasses for in situ tissue regeneration. J Biomater Sci Polym Ed. 2004;15(4): 543-62. [Medline: 15212333] [doi: 10.1163/156856204323005352]

23. Xynos ID, Hukkanen MV, Batten JJ, Buttery LD, Hench LL, Polak JM. Bioglass 45S5 stimulates osteoblast turnover and enhances bone formation In vitro: implications and applications for bone tissue engineering. Calcif Tissue Int. 2000 Oct;67(4):321-9. [Medline: 11000347] [doi: 10.1007/s002230001134]

24. Bosetti M, Cannas M. The effect of bioactive glasses on bone marrow stromal cells differentiation. Biomaterials. 2005 Jun;26(18):3873-9. [Medline: 15626435] [doi: 10.1016/j.biomaterials.2004.09.059]

25. Haimi S, Gorianc G, Moimas L, Lindroos B, Huhtala H, Räty S, Kuokkanen H, Sándor GK, Schmid C, Miettinen S, Suuronen R. Characterization of zinc-releasing three-dimensional bioactive glass scaffolds and their effect on human adipose stem cell proliferation and osteogenic differentiation. Acta Biomater. 2009 Oct;5(8):3122-31. [Medline: 19428318 ] [doi: $\underline{10.1016 / j . a c t b i o .2009 .04 .006]}$

26. Clokie CM, Sándor GK. Reconstruction of 10 major mandibular defects using bioimplants containing BMP-7. J Can Dent Assoc. 2008 Feb;74(1):67-72. [Medline: 18298888]

27. Tirkkonen L, Haimi S, Huttunen S, Wolff J, Pirhonen E, Sándor GK, Miettinen S. Osteogenic medium is superior to growth factors in differentiation of human adipose stem cells towards bone-forming cells in 3D culture. Eur Cell Mater. 2013 Jan 30;25:144-58. [Medline: 23361609] [doi: 10.22203/eCM.v025a10]

28. Woloszyk A, Holsten Dircksen S, Bostanci N, Müller R, Hofmann S, Mitsiadis TA. Influence of the mechanical environment on the engineering of mineralised tissues using human dental pulp stem cells and silk fibroin scaffolds. PLoS One. 2014 Oct 29;9(10):e111010. [Medline: 25354351] [PMC free article: 4213001] [doi: 10.1371/journal.pone.0111010]

29. d'Aquino R, De Rosa A, Lanza V, Tirino V, Laino L, Graziano A, Desiderio V, Laino G, Papaccio G. Human mandible bone defect repair by the grafting of dental pulp stem/progenitor cells and collagen sponge biocomplexes. Eur Cell Mater. 2009 Nov 12;18:75-83. [Medline: 19908196] [doi: 10.22203/eCM.v018a07]

30. Batouli S, Miura M, Brahim J, Tsutsui TW, Fisher LW, Gronthos S, Robey PG, Shi S. Comparison of stemcell-mediated osteogenesis and dentinogenesis. J Dent Res. 2003 Dec;82(12):976-81. [Medline: 14630898] [doi: $10.1177 / 154405910308201208]$

31. Shi S, Robey PG, Gronthos S. Comparison of human dental pulp and bone marrow stromal stem cells by cDNA microarray analysis. Bone. 2001 Dec;29(6):532-9. [Medline: 11728923] [doi: 10.1016/S8756-3282(01)00612-3]

32. Giuliani A, Manescu A, Langer M, Rustichelli F, Desiderio V, Paino F, De Rosa A, Laino L, d'Aquino R, Tirino V, Papaccio G. Three years after transplants in human mandibles, histological and in-line holotomography revealed that stem cells regenerated a compact rather than a spongy bone: biological and clinical implications. Stem Cells Transl Med. 2013 Apr;2(4):316-24. [Medline: 23502599] [PMC free article: 3659838] [doi: 10.5966/sctm.2012-0136]

33. Huang GT, Gronthos S, Shi S. Mesenchymal stem cells derived from dental tissues vs. those from other sources: their biology and role in regenerative medicine. J Dent Res. 2009 Sep;88(9):792-806. [Medline: 19767575] [PMC free article: 2830488] [doi: 10.1177/0022034509340867] 
34. Leucht P, Minear S, Ten Berge D, Nusse R, Helms JA. Translating insights from development into regenerative medicine: the function of Wnts in bone biology. Semin Cell Dev Biol. 2008 Oct;19(5):434-43. [Medline: 18824114] [doi: 10.1016/j.semcdb.2008.09.002]

35. Leucht P, Kim JB, Helms JA. Beta-catenin-dependent Wnt signaling in mandibular bone regeneration. J Bone Joint Surg Am. 2008 Feb;90 Suppl 1:3-8. [Medline: 18292349] [doi: 10.2106/JBJS.G.01136]

\section{To cite this article:}

Raspini G, Wolff J, Helminen M, Raspini G, Raspini M, Sándor GK.

Dental Stem Cells Harvested from Third Molars Combined with Bioactive Glass Can Induce Signs of Bone Formation In Vitro

J Oral Maxillofac Res 2018;9(1):e2

URL: http:/www.ejomr.org/JOMR/archives/2018/1/e2/v9n1e2.pdf

doi: $10.5037 /$ jomr.2018.9102

Copyright (C Raspini G, Wolff J, Helminen M, Raspini G, Raspini M, Sándor GK. Published in the JOURNAL OF ORAL \& MAXILLOFACIAL RESEARCH (http://www.ejomr.org), 31 March 2018.

This is an open-access article, first published in the JOURNAL OF ORAL \& MAXILLOFACIAL RESEARCH, distributed under the terms of the Creative Commons Attribution-Noncommercial-No Derivative Works 3.0 Unported License, which permits unrestricted non-commercial use, distribution, and reproduction in any medium, provided the original work and is properly cited. The copyright, license information and link to the original publication on (http://www.ejomr.org) must be included. 